\title{
Trophic coupling between bacterial and phytoplanktonic compartments in shallow tropical reservoirs (Ivory Coast, West Africa)
}

\author{
Marc Bouvy ${ }^{1, *}$, Robert Arfi ${ }^{2}$, Philippe Cecchi ${ }^{3}$, Daniel Corbin ${ }^{3}$, Marc Pagano $^{2}$, \\ Lucien Saint-Jean ${ }^{2}$, Serge Thomas ${ }^{3}$
}

'ORSTOM/Departamento de Pesca, Universidade Federal Rural de Pernambouco, Rua D. Manoel de Medeiros - S/N

Dois Irmaoes, 52171030 Recife, PE, Brazil

${ }^{2} \mathrm{CRO} /$ ORSTOM, BP V18, Abidjan, Ivory Coast

${ }^{3}$ ORSTOM, BP 1434, Bouaké 01, Ivory Coast

\begin{abstract}
Biomass and production of bacterial and phytoplanktonic communities were measured during diurnal cycles at different stations in 3 shallow tropical reservoirs (Ivory Coast). Investigations were conducted in 1995 during 2 typical hydrological seasons (dry season in March and following rainy season in December). Bacterial production in the plankton ranged from 1.2 to $26.2 \mu \mathrm{g} \mathrm{Cl}^{-1} \mathrm{~h}^{-1}$ and bacterial biomass ranged from 11 to $163 \mathrm{\mu g} \mathrm{C} \mathrm{l}^{-1}$ A slope of $0.625(\mathrm{n}=93)$ for the regression of log-transformed bacterial biomass versus log-transformed production suggests that the bacteria were strongly controlled by bottom-up processes. Ratios between net primary production and bacterial production averaged $67 \%$ (range 38 to $140 \%$ ), indicating that the reservoirs studied can be considered as mesoeutrophic ecosystems. Average bacterial carbon demand corresponded to $97 \%$ of the net primary production, suggesting that the biological systems studied are based on autotrophic metabolism. These relationships are the result of a close metabolic coupling between bacterioplankton and phytoplankton, with a large fraction of primary production routed through heterotrophic bacteria and the microbial loop
\end{abstract}

KEY WORDS: Bacteria - Phytoplankton - Eutrophication · Tropical reservoirs

\section{INTRODUCTION}

As shown by many theoretical, experimental and empirical studies (see reviews by Hunter \& Price 1992. Hairston \& Hairston 1993), the abundance of organisms within a particular trophic level is likely to be controlled by predation and/or by resource availability. Recent developments of methods have allowed ecologists to examine factors that control diversity and abundance of individuals and species of microorganisms in nature. Bacterial dynamics is influenced by environmental factors, like temperature, in temperate regions (White et al. 1991). Grazing pressure exerted by predators and/or the availability of resources (avail-

·E-mail: bouvy@cyb.com.br able organic matter or nutrients) can also control bacterioplankton dynamics (Billen et al. 1990). These topdown and bottom-up controls do not exist alternately but often operate simultaneously.

Generally, predators control the fate of bacterial production and heterotrophic flagellates tend to be the major bacterivores in freshwater (Sanders et al. 1989). However, ciliates, rotifers and cladocerans may also be significant consumers of bacteria (Pace et al. 1990, Bouvy et al. 1994). Other loss factors (e.g. lysis, viruses, antibiotics) may also contribute to bacterial mortality but their contributions remain unclear (Pace 1988).

Phytoplankton can directly supply bacteria with organic carbon through exudation from healthy cells and lysis of senescent and dead cells (Lancelot \& Billen 1984, Vadstein et al. 1993). Correlations between direct counts of pelagic bacteria and chlorophyll a con- 
centrations suggest that phytoplankton contributes to the organic carbon required to support bacterial growth (Bird \& Kalff 1984, Findlay et al. 1991), Bacterial production and net primary production were also correlated with a mean ratio of about $30 \%$ (5 to $50 \%$ ) across a wide range of trophic states (Bird \& Kalff 1984 , Cole et al. 1988). Based on a compilation of published rates of phytoplanktonic production and plankton community respiration, del Giorgio \& Peters (1993) suggested that plankton respiration (and in particular bacterial respiration) exceeds primary production in oligotrophic lakes. However, while bacteria appear to satisfy much of their carbon requirement from phytoplankton, these 2 components also compete for inorganic nutrients, sometimes inducing large variations between bacterial and phytoplanktonic production (Currie 1990, Le et al. 1994).

These ecological considerations are treated in a large number of studies conducted in temperate lakes (e.g. Sanders et al. 1989, Pace et al. 1990, Wylie \& Currie 1991, Vadstein et al. 1993, Pace \& Cole 1994b, Gasol et al. 1995, Ochs et al. 1995). Information about tropical ecosystems, especially those located in West Africa, is still very scarce (Symoens et al. 1981, Delincé 1992, Talling 1992, Melack 1996) while the application of limnological information appears urgent to address social needs. Recently, Gopal \& Wetzel (1995) recognized that limnology has received little attention in the developing countries, particularly in the tropics. To our knowledge, no study has dealt with components of the pelagic microbial loop in any West African freshwater ecosystems. Microbial food webs should be considered not only as a controlling factor for bacterial activity but also as an important regulator for planktonic succession in eutrophic systems such as tropical reservoirs. The aims of this study were to provide basic data on bacterioplankton and phytoplankton (biomass and production) and on the interrelationships between these 2 compartments in 3 reservoirs located in the north of Ivory Coast. Trophic coupling between bacterial and phytoplanktonic components was also discussed through the following question: are bacterial communities in these tropical reservoirs mainly controlled by the availability of resources for maintenance and growth requirements?

\section{MATERIALS AND METHODS}

The study is focused on permanent artificial reservoirs located in the north of Ivory Coast $\left(8^{\circ}\right.$ to $10^{\circ} \mathrm{N}, 5^{\circ}$ to $6^{\circ} \mathrm{W}$; Fig. 1). Lakes were chosen with the assumption of a link between their main usage and their trophic status. The 3 lakes selected illustrate the principal situations observed in this area:

Nambengué is a small polymictic reservoir (area 10 ha, maximum depth 2 to $3 \mathrm{~m}$ ) in the north of this Soudano-Sahelian region. Several hundred cattle come daily to drink at the lake, with a significant enrichment of the ecosystem through their excrement.
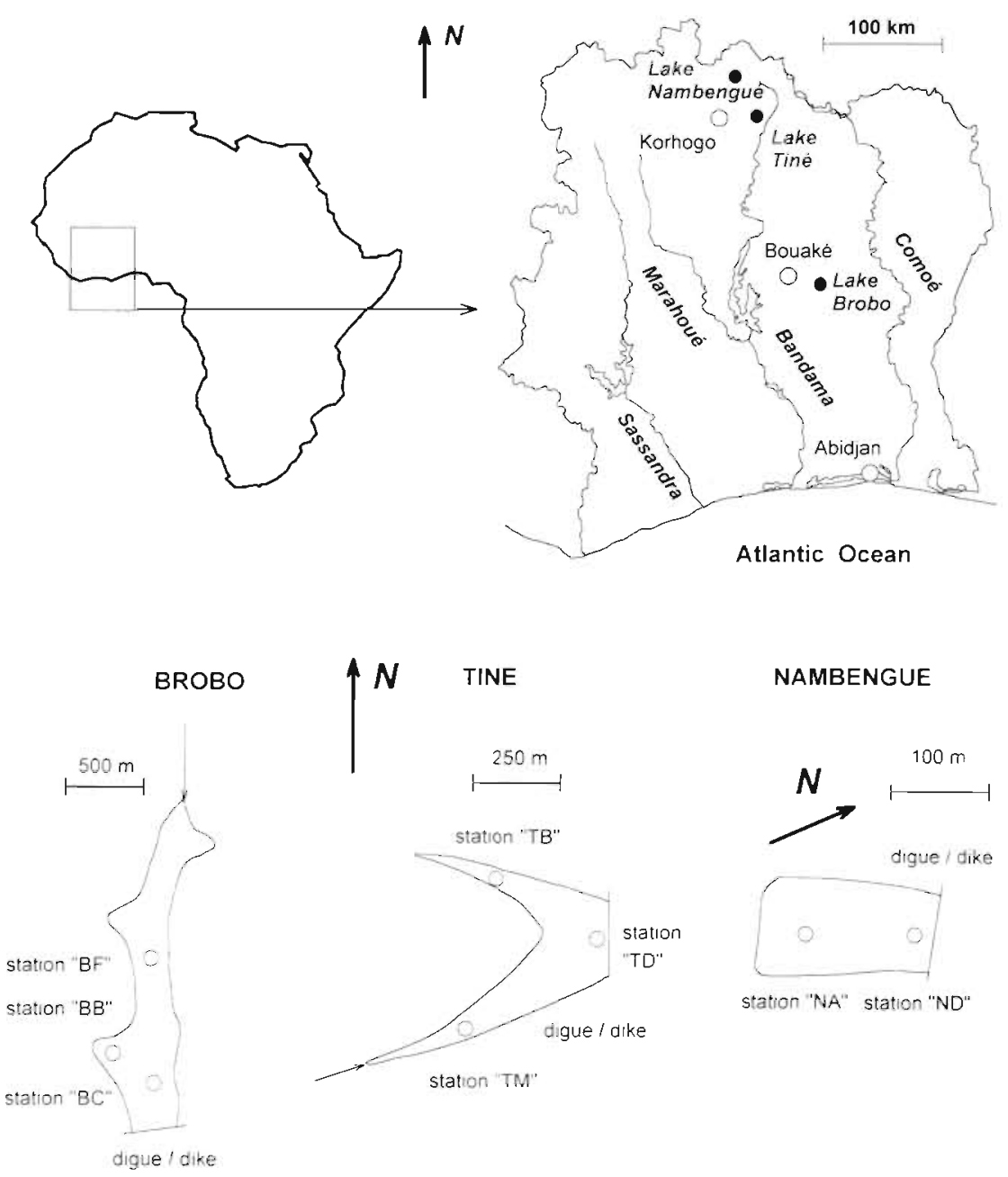

Fig. 1. Map of lvory Coast (West Africa) and location of the 3 reservoirs (Brobo. Tiné and Nambengué) and their respective sampling stations 
Tiné, also located in the north of the area, is a medium-sized polymictic reservoir $(45$ ha, maximum depth 6 to $7 \mathrm{~m}$ ), with transient stratification. Its primary use is for rice irrigation. This lake was selected because of the unique presence of the fish Lates niloticus that was introduced into the reservoir 20 yr ago. Because of its importance as predator, this species is known to potentially exert significant pressure on the whole pelagic food web structure (Lévêque 1995).

Brobo, in the south of the delimited region, is the largest reservoir studied (area 100 ha, maximum depth 7 to $8 \mathrm{~m}$ ). It is a private lake, with very slight pressure from human activities exerted on the ecosystem: no hydraulic constraint for irrigation and very little utilization by livestock. This lake is characterized by a regularly stratified water column with an anoxic hypolimnion. An obvious physical aspect is the great number of dead trees in the central part of the reservoir, although the impact on pelagic productivity is not known.

The choice of sampling stations in each lake was determined according to depth. For Tiné and Nambengué, there was a deep station in the downstream part of reservoirs, not far from the dikes (denoted TD, with 2 sampling levels, -0.5 and $-5 \mathrm{~m}$; and ND, with 2 sampling levels, -0.5 and $-2 \mathrm{~m}$ ), and 1 or 2 shallow stations (according to the number of tributaries) in the upstream part of reservoirs with subsurface sampling (TB and TM for Tiné and NA for Nambengué). For Brobo, there was the same kind of central station in the deepest part of the reservoir (denoted BC, with 3 sampling levels: $-0.5,-2.5$ and $-5 \mathrm{~m}$ ), an intermediate station among dead trees (BF, with 2 sampling levels: -0.5 and $-2 \mathrm{~m}$ ) and a shallow station near the west bank (BB, subsurface sampling: $-0.5 \mathrm{~m}$ ), instead of the upstream station.

Diel surveys were performed in Brobo and Nambengué in March 1995 (dry season) and in all 3 reservoirs in December 1995 (after the rainy season). Solar radiation was integrated hourly with a LiCor 200 pyranometer and a Li1000 data logger on the shore of each reservoir. Water was sampled with a 21 horizontal Niskin bottle at $5 \mathrm{~h}$ intervals for a total of up to $24 \mathrm{~h}$. In total, 13 surveys starting at 19:00 h were performed during this study. Temperature and conductivity were measured using a digital thermometer and a Tacussel conductivity meter, respectively. Light attenuation coefficients $(k)$ were calculated from vertical profiles using a LiCor 193 spherical quantum sensor $(4 \pi)$. Dissolved nutrients $\left(\mathrm{NH}_{4}-\mathrm{N}\right.$ and $\left.\mathrm{PO}_{4}-\mathrm{P}\right)$ were analyzed according to Strickland \& Parsons (1972). Chlorophyll a concentrations were determined by the fluorometric method on algae retained on Whatman GF/F filters and methanol extraction (Yentsch \& Menzel 1963). In a previous study conducted in desalted water on Ebrié Lagoon, Ivory Coast (Arfi \& Bouvy 1995), we deter- mined a C:chl ratio of 55 for large cells from measurements of carbon and chlorophyll change over time. For the present study, we adopted the C:chl ratio of 50 proposed by Eppley et al. (1977) to calculate algal carbon biomass. Primary production was measured with the ${ }^{14} \mathrm{C}$ uptake method. Replicate $125 \mathrm{ml}$ light and dark glass bottles were filled with subsurface water and $\mathrm{NaH}^{14} \mathrm{CO}_{3}$ (specific activity $3.7 \mathrm{MBq}$ mmol-1 ${ }^{-1}$ CEA, France) was added. Bottles were incubated in situ for 2 or $3 \mathrm{~h}$ around midday at 5 or 6 levels according to the maximum depth of the reservoir. Samples were then filtered onto Whatman GF/F filters and rinsed with $2 \%$ $\mathrm{HCl}$ followed by a rinse with filtered water. Radioactivity was determined by liquid scintillation (Beckman, LS 5000, external standards method). Gross productivity was integrated over the depth (trapeze method) and hourly data were extrapolated to daily values using solar radiation records and the ratio (light received during incubation time)/(light received over the whole day). To estimate net algal production, a percentage of $40 \%$ of the gross algal production corresponding to respiration is generally used (Likens 1975). In a previous study conducted in aquaculture ponds close to Ebrié Lagoon, we measured respiration values ranging between 28 and $42 \%$ (unpubl. data). In the same lagoon, Torréton (1991) used a value of $40 \%$ to assess net algal production from oxygen consumption experiments of phytoplanktonic and bacterial communities. In the 3 reservoirs studied, cyanobacteria and chlorophytes represent 70 to $90 \%$ of the phytoplankton (R. Arfi, M. Bouvy, P. Cecchi, M. Pagano \& L. Saint Jean unpubl.) and in such situations, respiration can represent 30 to $36 \%$ of the gross algal production (Langdon 1993). Therefore, we assumed an algal respiration value of $40 \%$ of the gross primary production.

Samples for determination of bacterioplankton were fixed with buffered formalin ( $2 \%$ final concentration) and stained with DAPI fluochrome (Porter \& Feig 1980). Bacterial cells were counted by epifluorescence microscopy (magnification $\times 1000$ ). Mean bacterial volumes were determined by measurements of up to 100 cells using photographic slides and a digitizing table. Cell volumes were computed with the formula described by Krambeck et al. (1981). Although there are uncertainties about the carbon:volume ratio for planktonic bacteria (Troussellier et al. 1997), carbon biomass was estimated assuming a conversion factor of $0.2 \mathrm{pg} C \mu \mathrm{m}^{-3}$ (Simon \& Azam 1989) because of the small size of bacteria measured in our study (mean biovolumes $<0.100 \mu^{3}$ ). Net bacterial production was measured by (methyl- ${ }^{3} \mathrm{H}$ )-thymidine incorporation into cold trichloroacetic acid (TCA) precipitate (Fuhrman \& Azam 1980). Linearity of the response over time and the saturation uptake by thymidine concentration were tested during preliminary evaluations. Incubation 
times ranged from $15 \mathrm{~min}$ (Nambengué) to $30 \mathrm{~min}$ (Tiné and Brobo). A final concentration of $20 \mathrm{nM}$ was added assuming that isotope dilution can be prevented at this concentration (see Robarts \& Zohary 1993). Duplicates and a control (zero time) were incubated with (methyl- ${ }^{3} \mathrm{H}$ )-thymidine $\left(47 \mathrm{Ci} \mathrm{mmol}^{-1}\right.$, Amersham) in the dark at in situ temperature. Incorporation of ${ }^{3} \mathrm{H}$ thymidine was stopped by adding ice-cold 5\% (final concentration) TCA for 5 min. Radioactivity was counted by the liquid scintillation procedure and results were expressed as nmols of incorporated thymidine per litre per hour. No previous information about thymidine incorporation rates in these ecosystems was available. A conversion factor for each ecological situation was determined empirically to convert rates of thymidine incorporation into bacterial biomass production, using the approaches outlined by Riemann et al. (1987) and Ducklow (1992). A dilution-growth experiment was conducted at each survey by comparing the increase in cell numbers with the total amount of substrate incorporated (integrative method). Duplicate bottles were incubated (in the dark at $0^{\circ} \mathrm{C}$ ) with water samples (filtered through a $1 \mu \mathrm{m}$ pore-size filter to remove predators) diluted at a ratio of 1:9 with filtered water (pore size $0.22 \mu \mathrm{m}$ ). Subsamples were removed at 2 to $3 \mathrm{~h}$ intervals for a total of 14 to $20 \mathrm{~h}$, depending on the reservoir. Biovolumes and abundances of bacterial cells and ${ }^{3} \mathrm{H}$-thymidine incorporation were determined at each sampling as described above. The absence of flagellates was checked at each enumeration of bacterial abundance. Exponential increase rates were determined by the slopes of the different regressions (abundance, biomass, thymidine incorporation) versus time.

Data were analyzed using the statistical package SigmaStat (Jandel Corp.). Since the normality test failed, comparisons between data sets were performed using a Mann-Whitney nonparametric test. To obtain conversion factors for bacterial biomass production, bacterial abundance and biomass and thymidine incorporation, these data were natural log transformed to meet the normality assumptions of a least-squares regression analysis. Normality of transformed data and residual values for each regression was tested by the Kolmogorov-Smirnov test. Each error created after back transformation from logarithmic to arithmetic scale (Sprugel 1983) was corrected by a conversion factor (CF).

\section{RESULTS}

\section{Physical and chemical characteristics of the water column}

Values for the main physical and chemical features of each reservoir for the 2 seasons are presented in Table 1. Nambengué is a shallow reservoir, where the water column is mixed most of the time. Abiotic parameters showed limited variations, and this site can be defined as a warm polymictic system. It was also very turbid, with a photosynthetically active radiation (PAR)

Table 1. Averages $(n=5)$ and standard deviation (in parentheses) of the physical and chemical variables for the 2 surveys at 2 depths. nd: not measured

\begin{tabular}{|c|c|c|c|c|c|c|c|c|c|c|}
\hline & \multicolumn{4}{|c|}{ Brobo } & \multicolumn{4}{|c|}{ Nambengué } & \multirow{2}{*}{\multicolumn{2}{|c|}{$\begin{array}{c}\text { Tiné } \\
\text { December }\end{array}$}} \\
\hline & \multicolumn{2}{|c|}{ March } & \multicolumn{2}{|c|}{ December } & \multicolumn{2}{|c|}{ March } & \multicolumn{2}{|c|}{ December } & & \\
\hline & $0.5 \mathrm{~m}$ & $5 \mathrm{~m}$ & $0.5 \mathrm{~m}$ & $5 \mathrm{~m}$ & $0.5 \mathrm{~m}$ & $2 \mathrm{~m}$ & $0.5 \mathrm{~m}$ & $2 \mathrm{~m}$ & $0.5 \mathrm{~m}$ & $5 \mathrm{~m}$ \\
\hline Temperature $\left({ }^{\circ} \mathrm{C}\right)$ & $\begin{array}{l}30.1 \\
(0.8)\end{array}$ & $\begin{array}{l}27.5 \\
(0.3)\end{array}$ & $\begin{array}{l}28.9 \\
(0.5)\end{array}$ & $\begin{array}{l}27.8 \\
(0.3)\end{array}$ & $\begin{array}{l}30.4 \\
(1.2)\end{array}$ & $\begin{array}{l}29.6 \\
(0.6)\end{array}$ & $\begin{array}{l}24.9 \\
10.9)\end{array}$ & $\begin{array}{l}24.1 \\
(0.3)\end{array}$ & $\begin{array}{l}26.8 \\
(0.3)\end{array}$ & $\begin{array}{l}26.4 \\
(0.2)\end{array}$ \\
\hline $\begin{array}{l}\text { Conductivity } \\
\left(\mu \mathrm{S} \mathrm{cm}^{-1}\right)\end{array}$ & $\begin{array}{l}69.9 \\
(2.0)\end{array}$ & $\begin{array}{l}73.3 \\
(3.8)\end{array}$ & nd & nd & $\begin{array}{l}164.4 \\
(7.0)\end{array}$ & $\begin{array}{l}163.7 \\
(5.7)\end{array}$ & nd & nd & nd & nd \\
\hline $\mathrm{pH}$ & $\begin{array}{c}8.30 \\
(0.25)\end{array}$ & $\begin{array}{l}7.61 \\
(0.12)\end{array}$ & nd & nd & $\begin{array}{c}7.76 \\
(0.20)\end{array}$ & $\begin{array}{c}7.62 \\
(0.12)\end{array}$ & nd & nd & nd & nd \\
\hline $\begin{array}{l}\text { Solar radiation } \\
\left(\mathrm{W} \mathrm{m}^{-2} \mathrm{~d}^{-1}\right)\end{array}$ & 5823 & - & 431.8 & - & 5475 & - & 4564 & - & 4989 & - \\
\hline Light attenuation ( $\mathrm{m}^{-}$ & $\left.i^{-1}\right)$ & & & 2 & 4. & & 2 & & & \\
\hline $\begin{array}{l}\text { Depth of the } \\
1 \% \text { irradiance }(\mathrm{m})\end{array}$ & 3. & & & 8 & 1. & & 1 & & & \\
\hline $\mathrm{NH}_{4}-\mathrm{N}(\mu \mathrm{M})$ & $\begin{array}{c}1.82 \\
(0.62)\end{array}$ & $\begin{array}{l}21.42 \\
(4.80)\end{array}$ & $\begin{array}{c}4.22 \\
(2.79)\end{array}$ & $\begin{array}{l}3.88 \\
(3.30)\end{array}$ & $\begin{array}{l}2.85 \\
(1.04)\end{array}$ & $\begin{array}{l}40.51 \\
(4.03)\end{array}$ & $\begin{array}{l}3.03 \\
(1.75)\end{array}$ & $\begin{array}{l}3.54 \\
(2.66)\end{array}$ & $\begin{array}{l}3.85 \\
(1.73)\end{array}$ & $\begin{array}{c}5.27 \\
(1.85)\end{array}$ \\
\hline $\mathrm{PO}_{4}-\mathrm{P}(\mu \mathrm{M})$ & $\begin{array}{c}0.21 \\
(0.08)\end{array}$ & $\begin{array}{c}0.23 \\
(0.13)\end{array}$ & $\begin{array}{c}0.17 \\
(0.07)\end{array}$ & $\begin{array}{c}0.13 \\
(0.08)\end{array}$ & $\begin{array}{c}0.09 \\
(0.02)\end{array}$ & $\begin{array}{c}0.04 \\
(0.02)\end{array}$ & $\begin{array}{c}0.08 \\
(0.02)\end{array}$ & $\begin{array}{l}0.08 \\
(0.01)\end{array}$ & $\begin{array}{c}0.10 \\
(0.05)\end{array}$ & $\begin{array}{c}0.09 \\
(0.02)\end{array}$ \\
\hline
\end{tabular}


attenuation coefficient of $4.5 \mathrm{~m}^{-1}$ in March and $2.4 \mathrm{~m}^{-1}$ in December. The corresponding photic zone, defined as a zone receiving at least $1 \%$ of total irradiance, was 1.0 and $1.9 \mathrm{~m}$, respectively. In contrast, Brobo and Tiné were thermally stratified with an aerobic layer to a depth of $4 \mathrm{~m}$. PAR attenuation coefficients in Brobo and Tiné were close to $1.3 \mathrm{~m}^{-1}$ for both seasons, and the corresponding photic zone was around $3.5 \mathrm{~m}$. In the superficial layer, ammonia concentrations in March and December were similar, with respective means of 1.82 and $4.22 \mu \mathrm{M}$ at Brobo and 2.85 and $3.03 \mu \mathrm{M}$ at Nambengué. At maximum depths, values were high, particularly in March (21.42 and 40.51 $\mu \mathrm{M}$, respectively, at Brobo and Nambengué). Ammonia values at Tiné in December were similar to those reported at Brobo (Table 1). High orthophosphate con- centrations were found at Brobo and average values were significantly different between the 2 seasons studied (Mann-Whitney test, $p<0.001$ ). Phosphate concentrations were not significantly different at Tiné and Nambengué.

\section{Bacterial and phytoplanktonic biomass}

Abundance and biomass of both bacteria and phytoplankton were significantly higher during the dry season (Mann-Whitney test, $\mathrm{p}<0.01$ ), except for 1 station at Brobo (hypolimmic zone at the central station; Table 2). The highest bacterial abundances were always found at Nambengué, with mean values ranging between $0.34 \times 10^{10}$ and $1.10 \times 10^{10}$ cells $1^{-1}$

Table 2. Averages $(\mathrm{n}=5$ ) and coefficients of variation (\%, in parentheses) for bacterial (density, biovolume and biomass) and phytoplankton (chlorophyll concentration and biomass) communities at 2 seasons for each depth

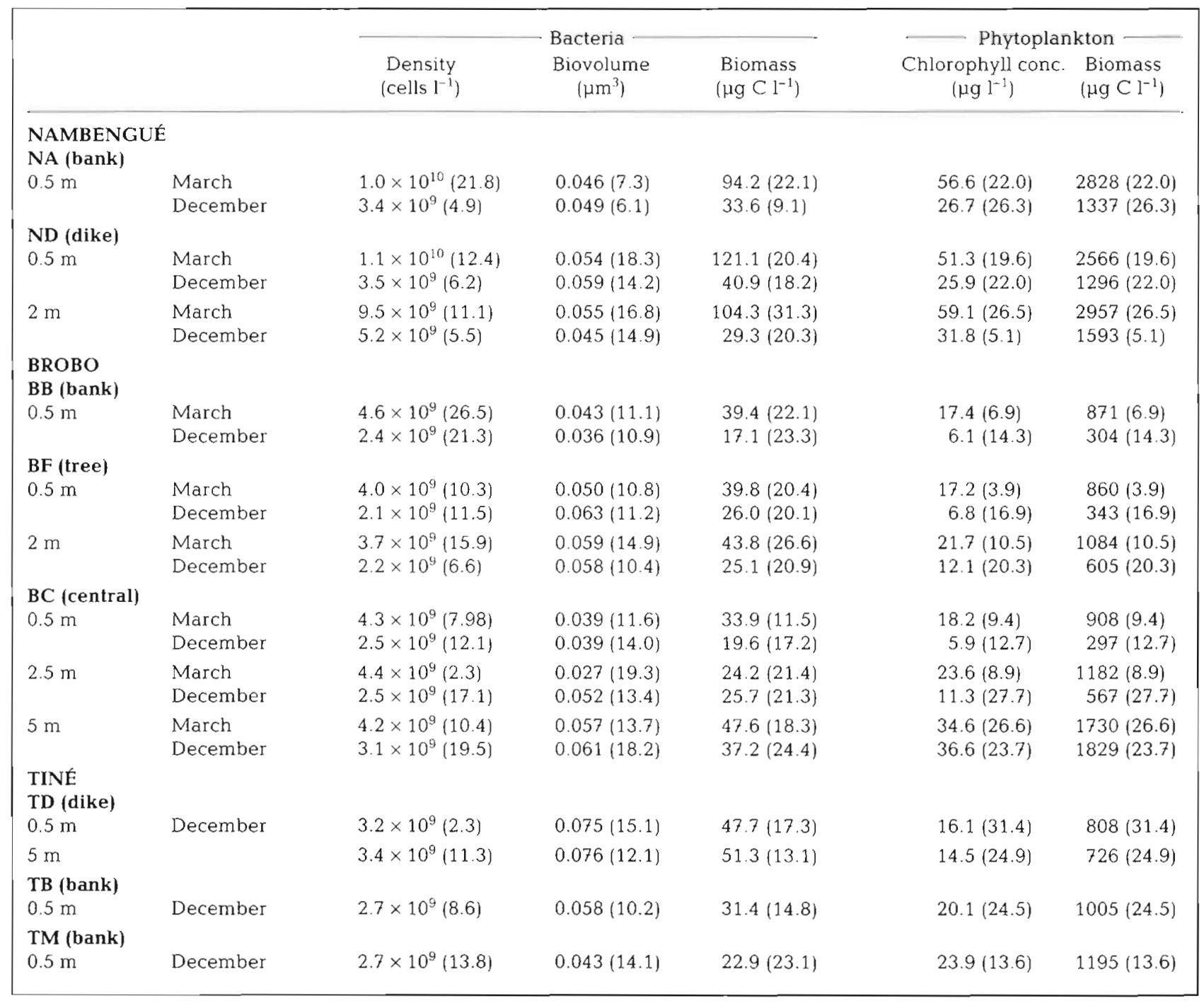


(Table 2). In this reservoir, whatever the season, no variability with depth was detected at the dike station (ND). Mean bacterial biovolume fluctuated between 0.045 and $0.059 \mu^{3}$ with the lowest values found at the bank station (NA). As observed in Nambengué, bacterial abundances were not significantly different at Brobo at different depths (Table 2). Mean bacterial biovolumes were small and showed little variation,

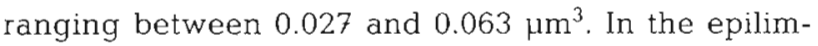
nion, chlorophyll concentrations ranged between 6.8 and $21.7 \mu \mathrm{g} \mathrm{I}^{-1}$, with high values found at $0.5 \mathrm{~m}$ in March. In the hypolimnic layer at the central station (BC) in Brobo, bacterial volumes were the highest reported for this reservoir (Table 2) and chlorophyll concentrations were close to $35 \mu^{-1} \mathrm{l}^{-1}$ whatever the season. At Tiné in December, bacterial abundances were similar across stations and depths (Table 2) but bacterial biovolumes and biomasses were greatest at the dike station (TD). In this reservoir, chlorophyll concentrations ranged between 14.5 and $23.9 \mathrm{\mu g} \mathrm{l}^{-1}$. In Nambengué, chlorophyll concentrations were always high and ranged between $25.9 \mu \mathrm{g} \mathrm{l}^{-1}$ in December and $59.1 \mathrm{\mu g} \mathrm{l}^{-1}$ in March.

\section{Bacterial and phytoplanktonic production}

Empirical factors converting thymidine incorporation rates into bacterial production were estimated by dilution cultures during which bacterial abundance increased exponentially. Average growth rates of abundance and biomass were always significant during the culture until the beginning of the plateau and accounted for 86 to $99 \%$ of the variance (see $r^{2}$ in Table 3 , except 1 value). Conversion factors calculated by an integrative method may be computed if similar growth rates are detected between thymidine incorporation rates and cell or biomass production. Cell production per mole of thymidine incorporated (Tdr-cell) and biomass production per mole of thymidine incorporated (Tdr-biom) are reported in Table 3. If thymidine uptake was closely coupled with cell growth rates, the increase rates in bacterial number should be close to the increase rate in thymidine incorporation. In our study, this was the case for the bacterial communities in Nambengué (in March and December) and in Brobo (in March). Thus, the conversion factor from incorporation rate and cell number was used for each situation $\left(0.93,1.69\right.$ and $2.56 \times 10^{18}$ cells mol ${ }^{-1}$ thymidine incorporated, respectively; Table 3). In the other cases (Brobo and Tiné in December), thymidine uptake was closely coupled with biomass growth rates, underlining the large variation of the mean volume of cells produced. For these situations, we used biovolumebased conversion factors $\left(0.56\right.$ and $4.38 \times 10^{17} \mu^{3}$ mol $^{-1}$ thymidine incorporated, respectively, at Brobo and Tiné).

Means of thymidine incorporation rates ranged from 0.108 to $1.792 \mathrm{nmol} \mathrm{l}^{-1} \mathrm{~h}^{-1}$ (Table 4) with the highest values observed in Nambengué. These values were always significantly higher in March than in December (Mann-Whitney test, $\mathrm{p}<0.001$ ), with coefficients of

Table 3. Conversion factor experiments from dilution cultures. Tdr: thymidine incorporation (log pmol thymidine $\mathrm{l}^{-1} \mathrm{~h}^{-1}$ ); cell: bacterial abundance $\left(\log 10^{9}\right.$ cells $\left.\mathrm{l}^{-1}\right)$; biom: bacterial biomass $\left(\log 10^{6} \mu \mathrm{m}^{3} \mathrm{I}^{-1}\right)$. Conversion factors are expressed in $10^{18} \mathrm{cells}^{\mathrm{mol}} \mathrm{l}^{-1}$ thymidine incorporated (Tdr-cell) and in $10^{17} \mathrm{\mu m}^{3} \mathrm{~mol}^{-1}$ thymidine incorporated (Tdr-biom). Conversion factors used in the text are in bold

\begin{tabular}{|c|c|c|c|c|c|c|c|c|c|}
\hline Season & Parameter & Slope & $(\mathrm{SE})$ & Intercept & (SE) & $r^{2}$ & Growth & \multicolumn{2}{|c|}{ Conversion facto } \\
\hline \multicolumn{10}{|c|}{ Nambengué } \\
\hline \multirow[t]{3}{*}{ March } & $\mathrm{Tdr}$ & 0.095 & 0.011 & 1.401 & 0.052 & 0.964 & 0.218 & & \\
\hline & cell & 0.088 & 0.013 & -0.881 & 0.078 & 0.981 & 0.202 & 0.93 & Tdr-cell \\
\hline & biom & 0.191 & 0.029 & 0.871 & 0.184 & 0.976 & 0.43 .9 & 5.01 & Tdr-biom \\
\hline \multirow[t]{3}{*}{ December } & $T d r$ & 0.037 & 0.006 & 1.481 & 0.051 & 0.908 & 0.085 & & \\
\hline & cell & 0.027 & 0.002 & -0.369 & 0.021 & 0.935 & 0.062 & 1.69 & Tdr-cell \\
\hline & biom & 0.079 & 0.038 & 1.181 & 0.374 & 0.586 & 0.181 & 2.88 & Tdr-biom \\
\hline \multicolumn{10}{|l|}{ Brobo } \\
\hline \multirow[t]{3}{*}{ March } & $\mathrm{Tdr}$ & 0.055 & 0.006 & 0.913 & 0.058 & 0.965 & 0.126 & & \\
\hline & cell & 0.041 & 0.016 & -0.243 & 0.192 & 0.865 & 0.094 & 2.56 & Tdr-cell \\
\hline & biom & 0.145 & 0.018 & 0.893 & 0.216 & 0.984 & 0.333 & 20.8 & Tdr-biom \\
\hline \multirow[t]{3}{*}{ December } & $\mathrm{Tdr}$ & 0.099 & 0.021 & 1.331 & 0.157 & 0883 & 0.227 & & \\
\hline & cell & 0.042 & 0.006 & -0.783 & 0.046 & 0.896 & 0.096 & 19.7 & Tdr-cell \\
\hline & biom & 0.144 & 0.001 & 0.047 & 0.001 & 0.998 & 0.331 & 0.56 & Tdr-biom \\
\hline \multicolumn{10}{|l|}{ Tiné } \\
\hline \multirow[t]{3}{*}{ December } & $\mathrm{Tdr}$ & 0.052 & 0.004 & 1.241 & 0.041 & 0.974 & 0.119 & & \\
\hline & cell & 0.091 & 0.091 & -0.757 & 0.103 & 0.994 & 0.209 & 3.24 & Tdr-cell \\
\hline & biom & 0.081 & 0.081 & 1.281 & 0.007 & 0.946 & 0.186 & 4.38 & Tdr-biom \\
\hline
\end{tabular}


variation of 7.3 and $8.6 \%$ respectively (Table 4 ). Whatever the season, specific incorporation rates were higher in Nambengué than in the 2 other reservoirs. The specific incorporation rates in Nambengué were significantly higher in December than in March. Using the conversion factors measured for each reservoir, bacterial production was calculated from thymidine incorporation rate. A similar pattern was observed for bacterial biomass and production, with the highest values noted at Nambengué in March (>15 $\left.\mu \mathrm{g} \mathrm{C} \mathrm{l}^{-1} \mathrm{~h}^{-1}\right)$. The lowest production was found at Brobo in Decem-

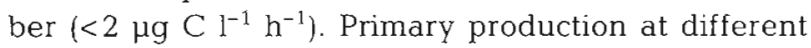

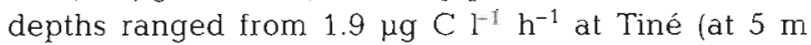

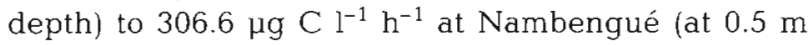
depth in March). The highest primary production was always measured in March, whatever the reservoir studied. Due to rapid light extinction with depth, ${ }^{14} \mathrm{C}$ fixation decreased strongly with depth (Table 4).

\section{DISCUSSION}

A body of literature exists on tropical freshwater ecosystems, but studies are generally diffuse and fragmentary. Eutrophication processes in tropical regions were debated by Thornton (1987) with many considerations for management. In a review, Lewis (1995) discussed food chain structure related to lake latitude, with a descriptive picture of tropical lakes and a comparison to temperate lakes. Melack (1996) emphasized

Table 4. Averages $(n=5)$ and coefficient of variation ( $\%$, in parentheses) for bacterial (thymidine incorporation rate, specific incorporation rate and biomass production) and phytoplanktonic (primary production) communities for 2 seasons and for each depth. nd: not determined

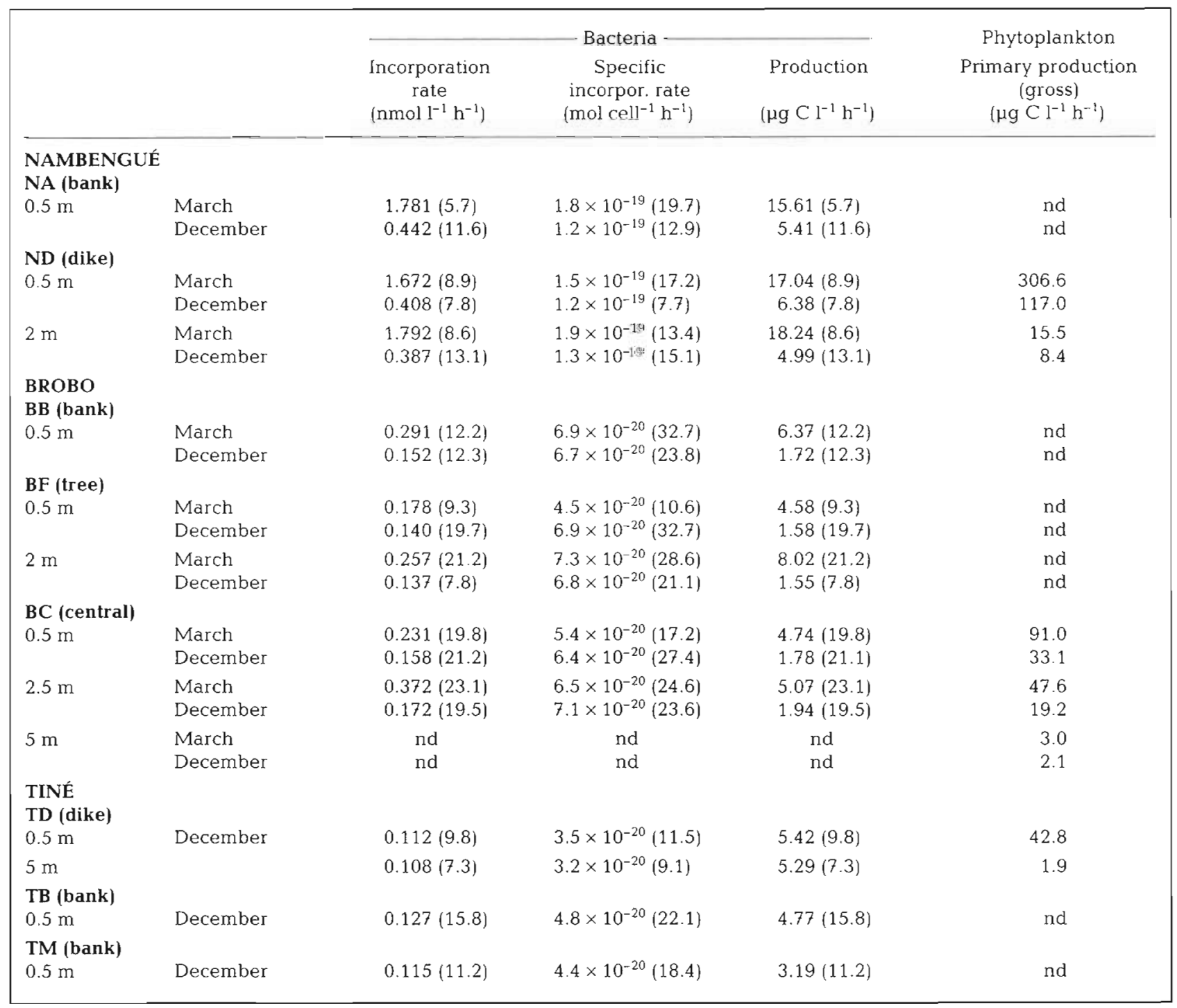


the recent developments of the nature and causes of variability in phytoplankton abundance and productivity in tropical countries. Many studies have been conducted on the ecology and distribution of tropical plankton (Lemoalle 1981 in some African lakes; Carmouze et al. 1983 in Lake Chad; Lewis et al. 1986 in Lake Valencia, Venezuela; Lind et al. 1992 and Chrzanowski et al. 1993 in Chapala Lake, Mexico; Haberyan et al. 1995 in some Costa Rican lakes), but very few studies have treated the bacterial and phytoplanktonic dynamics in freshwater lakes at these latitudes (e.g. Gebre-Mariam \& Taylor 1990 in Lake Awassa, Ethiopian Rift Valley; Tundisi et al. 1993 in many reservoirs in Brazil).

In tropical lakes, water temperature is generally linked to light irradiance. These 2 parameters show little variation and should not play a major role in the global functioning of reservoirs (Lewis 1995). Hydraulic changes linked to local perturbations and/or seasonal climatic events may represent the main control factor in reservoirs located in northern Ivory Coast. During the high water period (August to November), flooding creates an important dilution effect. These water inputs and these rains often induce drastic restructuring. Moreover, these shallow reservoirs are periodically (sometimes at a daily scale) mixed by local wind, inducing resuspension. During calm periods, diumal stratification of the upper water column generally occurs (P. Cecchi, D. Corbin \& S. Thomas unpubl.).

Bacterial abundances in the studied sites are among the highest abundances reported for reservoirs. Kilham (1981) found a bacterial density of $10^{11}$ cells $\mathrm{l}^{-1}$ from African soda lakes, whereas Gebre-Mariam \& Taylor (1990) reported a mean bacterial abundance of $6.2 \times 10^{9}$ cells $1^{-1}$ for Lake Awassa. In the reservoirs studied, bacterial communities were dominated by small bacteria, which resulted in exceptionally low bacterial biomass (product of abundance and biovolume). Apparently, the size of free-living bacteria does not reflect the trophic state of the environment (Simon 1987). Selective grazing exerted by predators upon the large cells of an assemblage could result in the selection of small individuals (Chrzanowski \& Simek 1990). Grazing and other loss factors, such lysis and viruses, seem to control microbial abundance in aquatic ecosystems and may approximately equal bacterial growth (e.g. Güde 1989). Bacterial production values reported in our study, assuming a daily bacterial production of 24 times the hourly rate, can rise to $400 \mu \mathrm{g} \mathrm{C}$ $\mathrm{l}^{-1} \mathrm{~d}^{-1}$ at Nambengué in March, and are at the higher end of the range of values reported by White et al.

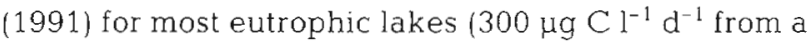
survey of 22 freshwater systems). Recently, Sommaruga (1995) in a hypertrophic lake (up to $330 \mu \mathrm{g} \mathrm{C}$ $\mathrm{l}^{-1}$ of chlorophyll a) found a mean bacterial production of $587 \mu \mathrm{g} \mathrm{Cl}^{-1} \mathrm{~d}^{-1}$ with a maximum of $1071 \mu \mathrm{g} \mathrm{Cl}^{-1} \mathrm{~d}^{-1}$ and explained it as an increase in bacterial production with increasing trophy. Our results also indicate increases in bacterial production along a trophic gradient from mesotrophy to eutrophy (based on chlorophyll concentrations ranging from 6.1 to $56.6 \mathrm{\mu g} \mathrm{1}^{-1}$ ) in the reservoirs we studied.

\section{Conversion factors}

The conversion factor of the thymidine uptake method has been used in many studies based on theoretical and empirical approaches. Very high variability is reported for this factor (see a review by Robarts \& Zohary 1993). Clearly, the choice of conversion factors and their combination with ${ }^{3} \mathrm{H}$ incorporation rates may have a major impact on the levels of bacterial biomass production calculated in any given study. Use of the empirical approach in this study is valid, by definition, even if $100 \%$ of thymidine is incorporated into protein. Indeed, a major problem is that thymidine incorporated into bacterial DNA is almost constant and dependent on environmental conditions. Using an enzymatic procedure in a previous study in a tropical area (Ebrié Lagoon, Ivory Coast), DNA labelling appeared to represent only $20 \%$ of the total labelled macromolecules (Torréton \& Bouvy 1991). In the present study (field conditions), it was not possible to assess the percentages of the different macromolecular fractions.

Our empirical conversion factors based on cell num-

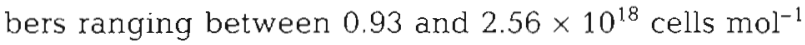
Tdr were close to the expected 'theoretical values' ( 1 to $2 \times 10^{18}$ cells $\mathrm{mol}^{-1} \mathrm{Tdr}$ ) reported by Bell (1990), In Ebrié Lagoon, Torréton et al. (1989) reported a low value of $0.73 \times 10^{18}$ cells $\mathrm{mol}^{-1} \mathrm{Tdr}$ despite the eutrophic context. In oligotrophic water cultures, Coveney \& Wetzel (1988) reported cell-number-based factors ranging from $1.1 \times 10^{18}$ to $38 \times 10^{18} \mathrm{cells} \mathrm{mol}^{-1}$ Tdr. From data obtained in tropical Lake Chapala, Chrzanowski et al. (1993) reported conversion factors ranging between $4.7 \times 10^{19}$ and $5 \times 10^{21}$ cells mol ${ }^{-1} \mathrm{Tdr}$, which are among the highest values ever published. In some cases in our study (Brobo and Tiné in December), incorporation of exogenous ${ }^{3} \mathrm{H}-\mathrm{Tdr}$ is coupled to total production of bacterial biomass rather than to production of new cells. This discrepancy (although not observed in Nambengué in December) can be linked to changes in environmental conditions after the rainy season. Thus, the apparent mean volume of cells produced increases considerably and leads to a positive relationship between cell size and DNA content. Coveney \& Wetzel (1988) empirically calculated a biovolume-based conversion factor $\left(15.2 \times 10^{17} \mu^{3} \mathrm{~mol}^{-1}\right.$ $\mathrm{Tdr}$ ) which is much larger than the factors calculated in 
our study $\left(0.56\right.$ and $4.38 \times 10^{17} \mu^{3} \mathrm{~mol}^{-1}$ thymidine incorporated in December at Brobo and Tiné, respectively). Other biovolume-based conversion factors from the literature are not available for comparison, although Coveney \& Wetzel (1988) concluded that those factors seem appropriate to convert ${ }^{3} \mathrm{H}$ incorporation rates to bacterial biomass production. Finally, we agree with the conclusion of Chrzanowski et al. (1993) that thymidine incorporation should not be considered as a routine assay of bacterial production. The determination of an empirical conversion factor appears necessary for each ecological situation and, clearly, all systems are characterized by biochemical and environmental specificities.

For further statistical analysis, the results from the hypolimnic layer at the central station of Brobo have not been included for 2 reasons. First, with the goal of homogeneity, our comparisons deal only with data from the oxygenated zone in all reservoirs. Second, many studies have recently proved that ${ }^{3} \mathrm{H}$-thymidine incorporation is not an appropriate technique for estimating secondary bacterial production in anaerobic systems (e.g. Lovell \& Konopka 1985).

\section{Bacterial biomass and production}

Bacterial production (BP) is the product of bacterial growth rate and bacterial biomass (BB) and is influenced by both top-down and bottom-up regulation. Kirchman (1993) suggested that temperature also may explain the variation of the $\mathrm{BP} / \mathrm{BB}$ ratio because bacterial abundance, production and growth rate are temperature dependent. In tropical regions, the small diurnal and seasonal fluctuations in temperature coupled with the high density-temperature coefficient of lake waters do not explain the variation of this ratio. From

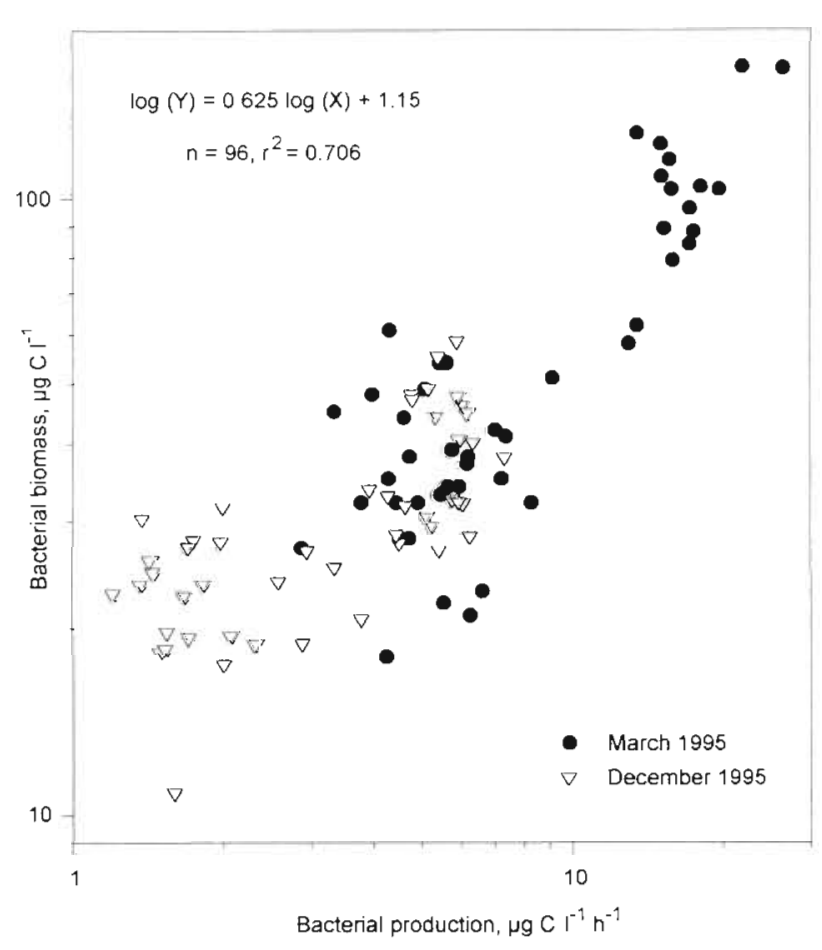

Fig. 2. Log-log linear regression of bacterial biomass on bacterial production in March and December 1995

all our data, BB and BP were significantly correlated (Fig. 2, Table 5), with the equation $\log (B B)=1.15+$ $0.625 \log (\mathrm{BP})$. Thus, bacterial growth rates tend to be higher in systems that are more productive. Bacterial biomass was a positive function of bacterial production, supporting the hypothesis developed by Billen et al. (1990), Ducklow (1992) and Pace \& Cole (1994b) that bacterial communities are strongly controlled by resources (bottom-up factors). The slope obtained in the present study was similar to those of Billen et al.

Table 5. Regression statistics (log-log transformed) and comparisons with other studies. Variables ( $Y, X$ ) are BB (bacterial bio-

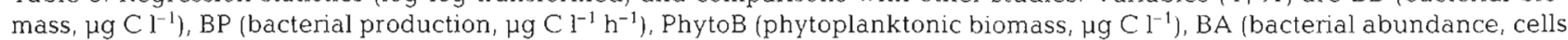
$\mathrm{I}^{-1}$ ) and PhytoA (chlorophyll concentration, $\mu \mathrm{g} \mathrm{1^{-1 }}$ ). $\mathrm{n}=$ number of data points; regression statistics (slope and intercept) are reported with their standard errors. Conversion factors (CF) are corrected for an inherent bias of log-transformed regressions (see 'Material and methods')

\begin{tabular}{|c|c|c|c|c|c|c|c|c|c|c|c|}
\hline Source & Y & $X$ & $\mathrm{n}$ & Slope & (SE) & Intercept & (SE) & $r^{2}$ & $F$ & $F$-test $\mathrm{p}$ & $\mathrm{CF}$ \\
\hline This study & $\mathrm{BB}$ & $\mathrm{BP}$ & 96 & 0.625 & 0.042 & 1.15 & 0.03 & 0.706 & 218.4 & $<0.001$ & 1.008 \\
\hline Billen et al. (1990) & $\mathrm{BB}$ & $\mathrm{BP}$ & 288 & 0.7 & - & 1.67 & - & 0.828 & - & - & - \\
\hline Ducklow (1992) & $\mathrm{BB}$ & $\mathrm{BP}$ & 210 & 0.43 & - & 1.67 & - & 0.803 & - & - & - \\
\hline Dufour \& Torréton (1996) & $\mathrm{BB}$ & $\mathrm{BP}$ & 68 & 0.48 & 0.01 & 1.68 & 0.03 & 0.921 & - & - & - \\
\hline This study & $\mathrm{BB}$ & PhytoB & 93 & 0.596 & 0.057 & -0.21 & 0.17 & 0.542 & 107.6 & $<0.001$ & 1.020 \\
\hline Simon et al. (1992) & $\mathrm{BB}$ & PhytoB & 104 & 0.219 & 0.031 & 1.39 & 0.07 & 0.34 & 53.1 & - & 1.340 \\
\hline This study & $\mathrm{BA}$ & PhytoA & 93 & 0.583 & 0.046 & 8.83 & 0.06 & 0.631 & 155.8 & $<0.001$ & 1.016 \\
\hline Cole et al. (1988) & $\mathrm{BA}$ & PhytoA & 32 & 0.53 & - & 8.97 & - & 0.75 & - & - & - \\
\hline Bird \& Kalff (1984) & $\mathrm{BA}$ & PhytoA & 13 & 0.569 & 0.271 & 9.27 & 0.19 & 0.66 & - & - & 1.087 \\
\hline
\end{tabular}




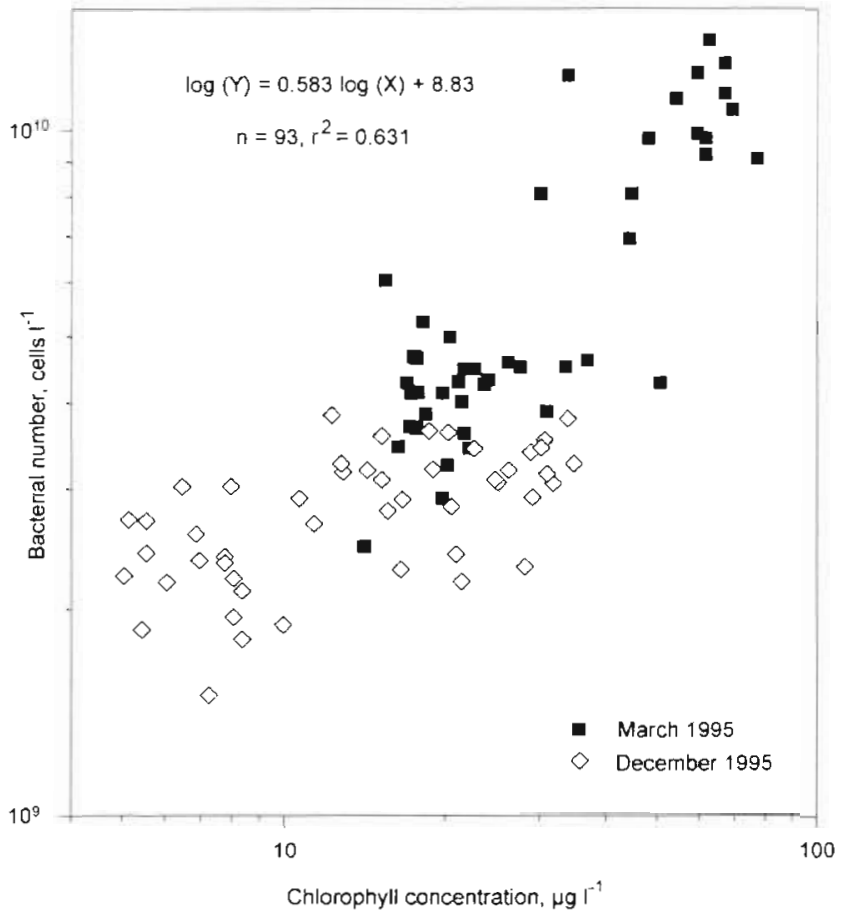

Fig. 3. Log-log linear regression between bacterioplankton abundance and chlorophyll a concentration in March and December 1995

(1990) and higher than those reported by Ducklow (1992) in oceanic regions and by Dufour \& Torréton (1996) in the tropical Northeastern Atlantic Ocean (Table 5). These authors linked this difference between oligotrophic and eutrophic systems to the availability of dissolved organic matter (DOM) in the system. With low concentrations of DOM (as in oligotrophic reservoirs), bacterial growth may be restricted, as in the case of oceanic regions. Nevertheless, bacterial abundance (total direct counts) is not a measure of biological activity. The proportion of active bacteria is highly variable among aquatic systems but forms a generally small fraction of the total bacterial abundance (del Giorgio \& Scarborough 1995). However, the data of del Giorgio \& Scarborough (1995) still support the hypothesis of substrate limitation because the proportion of active bacterial cells in freshwater and marine plankton increases with nutrient and chlorophyll concentrations

\section{Relationship between bacterial and phytoplanktonic biomass}

Many investigators have observed significant correlations between bacteria and chlorophyll $a$ in various ecosystems (Bird \& Kalff 1984, Cole et al. 1988, Duck- low \& Carlson 1992, Simon et al. 1992). All these relationships have been interpreted to be the result of a close metabolic coupling between bacterioplankton and phytoplankton. Experimental studies generally confirmed this interpretation (Pace \& Cole 1994a), although in certain conditions, concentrations of dissolved inorganic nutrients may be a critical factor that drives the apparent coupling between bacteria and phytoplankton (Le et al. 1994). In our study, a correlation was also observed between bacteria and phytoplankton (Fig. 3). Regressions based on both carbon biomass and cell abundance (Table 5) exhibit similar slopes (0.596 and 0.583, respectively). These slopes were comparable to those found by Cole et al. (1988) and Bird \& Kalff (1984). Simon et al. (1992) always found slopes less than 0.5 . This might suggest that bacterial biovolume is an important aspect of the structure of the pelagic food web.

The ratio between bacterial and phytoplanktonic biomass is generally high $(>1)$ in marine systems and low (<0.5) for limnetic and eutrophic systems characterized by phytoplankton biomasses greater than $250 \mu \mathrm{g} \mathrm{C}^{-1}$ (Simon et al. 1992). In our study, the ratios were very low (average 0.043, range between 0.017 and $0.096, \mathrm{n}=96$ ) and tended to decrease with increasing phytoplankton biomass, as was expected for ecosystems of varying trophic state (e.g. Simon et al. 1992).

\section{Relationship between bacterial and primary production}

All data were converted to an areal basis from the depth of the photic zone for each reservoir. Net phytoplanktonic production ranged from 239 to $850 \mathrm{mg} \mathrm{C}$ $\mathrm{m}^{-2} \mathrm{~d}^{-1}$ and bacterial production (BP) varied between 136 and $846 \mathrm{mg} \mathrm{C} \mathrm{m}^{-2} \mathrm{~d}^{-1}$, representing most of the primary production (PP) values (Table 6 ). The $\mathrm{BP} / \mathrm{PP}$ ratio was quite similar during the study with a bacterioplankton production that reached an average of $67 \%$ of the net primary production (NPP). The highest value $(140 \%)$ was observed in March at Nambengué. Although the NPP at Brobo was lower in December than in March, the similarity in the BP/PP ratio between the 2 seasons implies that BP was stimulated in response to $\mathrm{PP}$ and to algal photosynthetic exudates. Finally, except for the data from Nambengué in March, values of bacterial production on an areal basis were high, reaching up to $49 \%$ of the NPP, although the average reported by Cole et al. (1988) only rose to $30 \%$.

Bacterial growth efficiency (BGE; percentage of organic carbon entering the bacterial cell that remains as living carbon) is now the subject of many controver- 
sies because very high variability is reported in the literature for this conversion factor (Cole \& Pace 1995, Jahnke \& Craven 1995). Most current models of aquatic carbon flow assume BGEs in the range of 40 to $50 \%$ (Cole \& Pace 1995). Recently, del Giorgio et al. (1997) suggested that BGE must range from <10 to $25 \%$ in most systems. However there appears to be a general trend of increasing BGE along gradients of system enrichment from $<10 \%$ in oligotrophic sites to a plateau of $40 \%$ in the most productive systems. In our study, NPP largely exceeded the threshold of 100 to $120 \mu \mathrm{g} \mathrm{C} \mathrm{l}^{-1} \mathrm{~d}^{-1}$ cited by del Giorgio et al. (1997) for unproductive systems, and we assume that the use of $40 \%$ is the most appropriate percentage for the BGE in our study. These authors also calculated that bacterial respiration tended to exceed NPP in unproductive aquatic systems with NPP below $100 \mu \mathrm{g} \mathrm{C} \mathrm{l}^{-1} \mathrm{~d}^{-1}$ (del Giorgio et al. 1997). Excluding the data from Nambengué in March, the average bacterial carbon demand (respiration) was $428 \mathrm{mg} \mathrm{C} \mathrm{m} \mathrm{C}^{-1}$, which corresponds to $69 \%$ of the NPP (Table 6). This suggests that in the reservoirs studied the biological systems are a net source of oxygen and that algal production is a primary source of organic substrates for bacteria.

In Nambengué reservoir in March, bacterial respiration exceeded the NPP (see Table 6) and bacteria must have used external sources of organic matter. This small reservoir is used daily by cattle and thus receives a high organic input during the dry season (March). In this eutrophic system, the high respiration of bacterioplankton relative to NPP can be explained by the availability of another source of DOM (cattle) during the dry season, the poor light penetration (light attenuation coefficient of $4.5 \mathrm{~m}^{-1}$ ) reducing the photic zone and potentially a high uptake of inorganic phosphorus by competitively dominant bacteria which can limit phytoplankton production (Currie 1990).

Our data suggest a high degree of trophic coupling between bacterial and phytoplanktonic components with photosynthetic exudates as a major dissolved organic source for bacterial growth. The ratio of heterotrophic bacterial production to phytoplankton production indicated carbon flow through the microbial food chain, and bacterial abundance and bacterial production were statistically correlated with phytoplankton biomass. However, this approach may over- or underestimate the effects of trophic coupling between algae and bacteria because this ratio may greatly fluctuate at diel scale or mesoscale (Hoch \& Kirchman 1993). Consequently, regulation of bacterial biomass and productivity by resources and predators should ultimately be evaluated by comparative and experimental studies (Pace \& Cole 1994a).

This first microbial study in this type of shallow tropical reservoir in West Africa reveals a marked control of heterotrophic bacterial communities exerted by the availability of resources (algal production). Our results corroborate the recent conclusions developed by del Giorgio et al. (1997) which suggest a tendency for net autotrophic metabolism in productive lakes and estu-

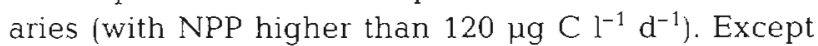
for the situation at Nambengue in March, the reservoirs studied can be considered as biological systems producing high levels of dissolved oxygen. However, this bottom-up control of bacterial biomass does not exclude regulation by predation (top-down factors). Indeed, bacterioplankton may be simultaneously controlled by heterotrophic flagellates since bacteria are

Table 6. Net bacterial production (NBP) and respiration, gross and net primary production (NPP) in the euphotic zone of the different reservoirs at the 2 seasons. Means for each variable with and without (in parentheses) the value of Nambengue in March are presented

\begin{tabular}{|c|c|c|c|c|c|c|}
\hline & \multirow[t]{2}{*}{$\begin{array}{l}\text { Euphotic } \\
\text { zone } \\
\text { (m) }\end{array}$} & \multirow{2}{*}{$\begin{array}{c}\text { Bacterial } \\
\text { production } \\
\left(\mathrm{mg} \mathrm{C} \mathrm{m}^{-2} \mathrm{~d}^{-1}\right) \\
\text { Net }\end{array}$} & \multirow[t]{2}{*}{$\begin{array}{c}\text { Bacterial } \\
\text { respiration } \\
\left(\mathrm{mg} \mathrm{C} \mathrm{m}^{-2} \mathrm{~d}^{-1}\right)\end{array}$} & \multicolumn{2}{|c|}{$\begin{array}{c}\text { Primary } \\
\text { production } \\
\left(\mathrm{mg} \mathrm{C}^{-2} \mathrm{~d}^{-1}\right)\end{array}$} & \multirow[t]{2}{*}{$\begin{array}{l}\text { NBP/NPP } \\
(\%)\end{array}$} \\
\hline & & & & Gross & $\mathrm{Net}^{\mathrm{a}}$ & \\
\hline \multicolumn{7}{|l|}{ March } \\
\hline Brobo & 3.5 & 414 & 621 & 1204 & 722 & 57 \\
\hline Nambengué & 1 & 846 & 1269 & 1005 & 603 & 140 \\
\hline \multicolumn{7}{|l|}{ December } \\
\hline Brobo & 3.5 & 136 & 204 & 399 & 239 & 57 \\
\hline Nambengué & 2 & 273 & 409 & 1085 & 651 & 42 \\
\hline Tiné & 3.5 & 320 & 480 & 1416 & 850 & 38 \\
\hline Mean & & $398(285)$ & $597(428)$ & $1022(1026)$ & $613(615)$ & $67(49)$ \\
\hline
\end{tabular}


an important source of carbon for these predators (Pace et al. 1990). High grazing rates by heterotrophic flagellates obtained from experiments based on labelled natural bacteria were noted in March at the 2 reservoirs (M. Bouvy, R. Arfi \& P. Cecchi unpubl.). The smaller bacterial biovolume obtained in our study may reflect the high grazing pressure exerted by heterotrophic protozoa. Thus, a significant amount of organic carbon produced by phytoplankton and released in dissolved form may be available for the upper trophic levels via bacteria and through the planktonic microbial loop in these tropical reservoirs.

Acknowledgements. We thank J. P. Torreton for his comments on the earlier draft, which greatly improved this manuscript. We also thank X. Lazzaro for correcting the English of a previous version. We are grateful to the 3 reviewers and to R. W. Sanders for criticism and constructive comments which helped considerably in improving manuscript content and style.

\section{LITERATURE CITED}

Arfi R, Bouvy M (1995) Size, composition and distribution of particles related to wind induced resuspension in a shallow tropical lagoon. J Plankton Res 17:557-574

Bell R (1990) An explanation for the variability in the conversion factor deriving bacterial cell production from incorporation of $\left({ }^{3} \mathrm{H}\right)$ thymidine. Limnol Oceanogr 35:910-915

Billen G, Servais P, Becquevort S (1990) Dynamics of bacterioplankton in oligotrophic and eutrophic aquatic environments: bottom-up or top-down control? Hydrobiologia 207:37-42

Bird DF, Kalff J (1984) Empirical relationships between bacterial abundance and chlorophyll concentrations in fresh and marine waters. Can J Fish Aquat Sci 41:1015-1023

Bouvy M, Arfi R, Guiral D, Pagano M, Saint-Jean L (1994) Role of bacteria as food for zooplankton in a eutrophic tropical pond (Ivory Coast). Neth J Aquat Ecol 28:167-174

Carmouze JP, Durand JR, Lévèque C (1983) Lake Chad: ecology and productivity of a shallow tropical ecosystem. Monographiae Biologica 53, Junk, The Hague

Chrzanowski TH. Simek K (1990) Prey-size selection by freshwater protozoans. Limnol Oceanogr 35:1425-1436

Chrzanowski TH, Simek K, Sada RH, Willaams S (1993) Estimates of bacterial growth rate constants from thymidine incorporation and variable conversion factors. Mirrob Ecol 25:121-130

Cole JJ, Findlay S, Pace ML (1988) Bacterlal production in fresh and saltwater ecosystems: a cross-system overview. Mar Ecol Prog Ser 43:1-10

Cole JJ, Pace ML (1995) Why measure bacterial production? A reply to the comment by Jahnke \& Craven. Limnol Oceanogr 40:441-444

Coveney MF, Wetzel RG (1988) Experimental evaluation of conversion factors for the ${ }^{3} \mathrm{H}$-thymidine incorporation assay of bacterial secondary productivity. Appl Environ Microbiol 54:2018-2026

Currie DJ (1990) Large scale variability and interactions among phytoplankton, bacterioplankton and phosphorus. Limnol Oceànogr 35:1437-1455

del Giorgio PA, Cole JJ, Cimbleris A (1997) Respiration rates in bacteria exceed phytoplankton production in unproductive aquatic systems. Nature 385:148-151

del Giorgio PA, Peters RH (1993) Balance between phytoplanktonic production and plankton respiration in lakes Can J Fish Aquat Sci 50:282-289

del Giorgio PA, Scarborough GA (1995) Increase in the proportion of metabolically active bactena along gradients of enrichment in freshwater and marine plankton: implications for estimates of bacterial growth and reproduction rates. J Plankton Res 17:1905-1924

Delince $G$ (1992) The ecology of the fish pond ecosystems with special reference to Africa. Dev Hydrobiol 72:1-230

Ducklow HW (1992) Factors regulating bottom-up control of bacterial biomass in open ocean communities. Arch Hydrobiol Beih 37:207-217

Ducklow HW, Carlson CA (1992) Oceanic bacterial production. Adv Microbiol Ecol 12:113-181.

Dufour P. Torréton JP (1996) Bottorn-up and top-down control of bacterioplankton from eutrophic to oligotrophic sites in the tropical northeastern Atlantic Ocean. Deep Sea Res 43:1305-1320

Eppley RW, Sharp JH, Renger EH, Perry MJ, Harrison WG (1977) Nitrogen assimilation by phytoplankton and other microorganisms in the surface waters of the central North Pacific Ocean. Mar Biol 39:111-120

Findlay S, Pace ML, Lints D, Cole JJ, Caraco NF, Peierls B (1991) Weak coupling of bacterial and algal production in a heterotrophic ecosystem: the Hudson river estuary. Limno] Oceanogr 36:268-278

Fuhrman JA, Azam F (1980) Bacterioplankton secondary production estimates for coastal waters of British Columbia, Antarctica, and California. Appl Environ Microbiol 39: $1085-1095$

Gasol JM, Simons AM, Kalff J (1995) Patterns in the top-down versus bottom-up regulation of heterotrophic nanoflagellates in temperate lakes. J Plankton Res 17:1879-1903

Gebre-Mariam Z, Taylor WD (1990) Heterotrophic bacterioplankton production and grazing mortality rates in an Ethiopian rift-valley lake (Awassa). Freshwat Biol 22: 369-381

Copal B, Wetzel RG (1995) Limnology in developing countries, Vol 1. International Association for Limnology, New Del.hi

Güde $H$ (1989) The role of grazing on bacteria in plankton. succession. In: Sommer U (ed) Plankton ecology. Springer, Berlin, p 337-354

Haberyan KA, Umana G, Collado C, Horn SP (1995) Observations on the plankton of some Costa Rican lakes. Hydrobiologia 312:75-85

Harston NG, Hairston NG Jr (1993) Cause effect relationships in energy flow, trophic structure, and interspecific interactions. Am Nat 142:379-411

Hoch MH. Kirchman DL (1993) Seasonal and inter-annual variability in bacterial production and biomass in a temperate estuary. Mar Ecol Prog Ser 98:283-295

Hunter MD, Price PW (1992) Playing chutes and ladders: heterogeneity and the relative roles of bottom-up and topdown forces in natural communities. Ecology 73:724-732

Jahnke RA, Craven DB (1995) Quantifying the role of heterotrophic bacteria in the carbon cycle: a need for respiration rate measurements. Limnol Oceanogr 40:436-441

Kilham P (1981) Pelagic bacteria: extreme abundances in African soda lakes. Naturwissenschaften 67:380

Kirchman. DL (1993) Bacterioplankton distributions and production in the northwestern Indian Ocean and Gulf of Oman, September 1986. Deep Sua Res 40:753-771

Krambeck C, Krambeck KHJ, Overbeck J (1981) Microcom- 
puter assisted biomass determination of plankton bacteria on scanning electron micrographs. Appl Environ Microbiol 42:142-149

Lancelot C, Billen G (1984) Activity of heterotrophic bacteria and its coupling to primary production during spring phytoplankton bloom in the Southern Bight of the North Sea. Limnol Oceanogr 29:721-730

Langdon C (1993) The significance of respiration in production measurements based on oxygen. ICES Mar Sci Symp $197: 69-78$

Le J, Wehr J, Campbell L (1994) Uncoupling of bacterioplankton and phytoplankton production in freshwaters is affected by inorganic nutrient limitation. Appl Environ Microbiol 60:2086-2093

Lemoalle J (1981) Photosynthetic production and phytoplankton in the euphotic zone of some African and temperate lakes. Rev Hydrobiol Trop 14:31-37

Lévêque $C$ (1995) Role and consequences of fish diversity in the functioning of African freshwater ecosystems: a review. Aquat Living Resour 8:59-78

Lewis WM (1995) Tropical lakes: how latitude makes a difference. In: Schiemer F, Boland KT (eds) Perspectives in tropical limnology. SPB Academic Publishing, Amsterdam, p $43-64$

Lewis WM, Frost T, Morris D (1986) Studies of planktonic bacteria in Lake Valencia, Venezuela. Arch Hydrobiol 106: 289-305

Likens CE (1975) Primary productivity of inland aquatic ecosystems. In: Lieth $\mathrm{H}$, Whittaker RH (eds) Primary production of the biosphere. Springer-Verlag, Berlin, p 185-202

Lind OT, Doyle R, Vodopich DS, Trotter BG, Limon JG, Davalos-Lind L (1992) Clay turbidity: regulation of phytoplankton production in a large, nutrient-rich tropical lake. Limnol Oceanogr 37:549-565

Lovell CR, Konopka A (1985) Seasonal bacterial production in a dimictic lake as measured by increases in cell numbers and thymidine incorporation. Appl Environ Microbiol 99: 492-500

Melack JM (1996) Recent developments in tropical limnology. Verh Int Verein Limnol 26:211-217

Ochs CA, Cole JJ, Likens GE (1995) Population dynamics of bacterioplankton in an oligotrophic lake. J Plankton Res 17:365-391

Pace ML (1988) Bacterial mortality and the fate of bacterial production. Hydrobiologia 159:41-49

Pace ML, Cole JJ (1994a) Comparative and experimental approaches to top-down and bottom-up regulation of bacteria. Microb Ecol 28:181-193

Pace ML, Cole JJ (1994b) Primary and bacterial production in lakes: are they coupled over depth? J Plankton Res 16: 661-672

Pace ML, McManus GB, Findlay SEG (1990) Planktonic community structure determines the fate of bacterial production in a temperate lake. Limnol Oceanogr 35:795-808

Porter KG, Feig YS (1980) The use of DAPI for identifying and counting aquatic microflora. Limnol Oceanogr 25:943-948

Riemann B, Bjornsen PK, Newell S, Fallon R (1987) Calculation of cell production of coastal marine bacteria based on measured incorporation of $\left({ }^{3} \mathrm{H}\right)$-thymidine. Limnol Oceanogr 32:471-476

Robarts RD, Zohary T (1993) Fact or fiction, bacterial growth

Editorial responsibility: Robert Sanders,

Philadelphia, Pennsylvania, USA rates and production as determined by (methyl ${ }^{3} \mathrm{H}$ ) thymidine? Adv Microbiol Ecol 13:371-425

Sanders RW, Porter KG, Bennett SJ, De Biase AE (1989) Seasonal patterns of bacterivory by flagellates, ciliates, rotifers, and cladocerans in a freshwater plankton community. Limnol Oceanogr 34:673-687

Simon M (1987) Biomass and production of small and large free-living and attached bacteria in Lake Constance. Limnol Oceanogr 32:591-607

Simon M, Azam F (1989) Protein content and protein synthesis rates of planktonic marine bacteria. Mar Ecol Prog Ser 51:203-213

Simon M, Cho BC, Azam F (1992) Significance of bacterial biomass in lakes and the ocean: comparison to phytoplankton biomass and biogeochemical implications. Mar Ecol Prog Ser 86:103-110

Sommaruga R (1995) Microbial and classical food webs: a visit to a hypertrophic lake. FEMS Microbiol Ecol 17:257-270

Sprugel DG (1983) Correcting for bias in log-transformed allometric equations. Ecology 64:209-210

Strickland JDH, Parsons TR (1972) A practical handbook of seawater analysis. Bull Fish Res Bd Can 167

Symoens JJ, Burgis M, Gaudet JJ (1981) The ecology and utilization of African inland waters. UNEP reports and proceedings series 1

Talling JF (1992) Environmental regulation in African shallow lakes and wetlands. Rev Hydrobiol Trop 25:87-144

Thornton JA (1987) Aspects of eutrophication management in tropical/sub-tropical regions. J Limnol Soc S Afr 13:25-43

Torréton JP (1991) Importance des bactéries hétérotrophes aérobies dans une lagune tropicale (Lagune Ebrié, Côte d'Ivoire). Biomasse, production, exportations. Thesis, Paris

Torréton JP, Bouvy M (1991) Estimating bacterial DNA synthesis from $\left({ }^{3} \mathrm{H}\right)$ thymidine incorporation: discrepancies among macromolecular extraction procedures. Limnol Oceanogr 36:299-306

Torréton JP, Guiral D, A.rfi R (1989) Bacterioplankton biomass and production during destratification in a monomictic eutrophic bay of a tropical lagoon. Mar Ecol Prog Ser 57: $53-67$

Troussellier M, Bouvy M, Courties C, Dupuy C (1997) Variation of carbon content among bacterial species under starvation condition. Aquat Microbiol Ecol 13:113-119

Tundisi JG, Matsumura-Tundisi T, Calijuri MC (1993) Limnology and management of reservoirs in Brazil. In: Straskraba M, Tundisi JG, Duncan A (eds) Comparative limnology and water quality management. Kluwer Academic Publishers, Dordrecht, p 25-55

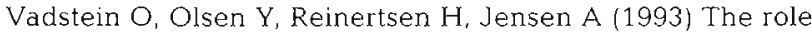
of planktonic bacteria in phosphorus cycling in lakes: sink and link. Limnol Oceanogr 38:1539-1544

White PA, Kalff J, Rasmussen JB, Gasol JM (1991) The effect of temperature and algal biomass on bacterial production and specific growth rate in freshwater and marine habitats. Microb Ecol 21:99-118

Wylie JL, Currie DJ (1991) The relative importance of bacteria and algae as food source for crustacean zooplankton. Limnol Oceanogr 36:708-728

Yentsch CS, Menzel DW (1963) A method for the determination of phytoplankton chlorophyll and pheophytin by fluorescence. Deep Sea Res 10:221-231

Submitted: February 15, 1997; Accepted: December 4, 1997

Proofs received from author(s): March 30, 1998 